\title{
REVITALISASI DAN PEMBERDAYAAN PERAJIN LUMUIK SULIKI, KEC. SULIKI, KABUPATEN LIMA PULUH KOTA, SUMATERA BARAT
}

\author{
Syahril $^{1}$, Ansosry ${ }^{2}$ \\ Fakultas Teknik, Universitas Negeri Padang \\ email : ${ }^{1}$ sy_ril@yahoo.com, ${ }^{2}$ ansosry@yahoo.co.id
}

\begin{abstract}
ABSRAK
Batu akik Lumuik Sulik dibuat dari batu mulia. Batu mulia adalah suatu mineral, setelah dipotong dan diasah, yang digunakan untuk membuat perhiasan atau ornamen lainnya. Kawasan Suliki, Kab.Lima Puluh Kota, Sumatera Barat tepatnya Suliki, terletak pada suatu dataran yang dikelilingi bukit-bukit memiliki potensi batu mulia dan telah lama dikenal sebagai penghasil batu akik yang dikenal sebagai Batu Lumuik Suliki. Akan dilakukan pelatihan dan pendampingan para pengrajin batu akik lumuik melalui program IbM. Telah dilakukan pembinaan para pengerajin batuakik Lumuik Suliki melalui program IbM. Target program $\mathrm{I}_{\mathrm{b}} \mathrm{M}$ Pengrajin batu akik lumuik Suliki, Kecamatan Suliki, Kabupaten Lima Puluh Kota, Sumatera Barat adalah adanya revitalisasi alat produksi, alih teknologi pengolahan batu mulia dan pemasaran produk-produk kerajinan batu akik Suliki sebagai usaha meningkatkan pamor Batu Akik Suliki dan peningkatan omset penjualan produk kerajinan batu akik Suliki dengan tanpa eksplorasi yang berlebihan terhadap bahan baku. Pembinaan pengerajin batuakik Lumuik Suliki dilakukan melalui latihan dan bimbingan intensif untuk menghasilkan produk yang diinginkan, melalui alur berikut: (i) pencarian batu mulia, (ii) pemilahan batu mulia berdasarkan jenisnya, (iii) pemotongan batu sesuai ukuran dan desain, (iv) proses menghaluskan dan mengkilapkan batu mulia, (v) pemilihan desain cincin, dll, dan (vi) pemasangan batu mulia sebagai permata. Pengerajin telah difasilitasi dengan beberapa peralatan untuk mengasah batu mulia menjadi permata. Adapun beberapa produk yang sudah dihasilkan antara lain cincin dari batu mulia dan cindra mata khas Suliki. Lebih lanjut telah dilakukan inventarisasi proses dan produk yang dihasilkan dari para pengerajin dengan membuat buku dan usaha untuk memasarkannya.
\end{abstract}

Kata Kunci : lumuik Suliki, pengrajin, revitalisasi, partisipati.

\section{PENDAHULUAN}

Batuakik lumuik suliki adalah satu dari sekian banyak jenis permata asli Indonesia. Batu alam dengan ciri khas warna unik dan menarik ini termasuk salah satu dari sekian banyak batu asal Sumatera yang sering menjadi incaran banyak penggemar dan kolektor, sehingga harganya semakin naik. Batu akik lumuik Suliki berasal dari pedalaman Kec. Suliki, Kab.Lima Puluh Kota, Sumatera Barat tepatnya di Jorong
Suliki Buruah, terletak pada suatu dataran yang dikelilingi bukit-bukit dan tebing yang curam. Medan seperti ini menjadikan jorong ini sulit untuk dijejalahi dan jarang penduduknya dan merupakan salah satu daerah penghasil batu alam indah selain beberapa daerah lain yang ada di kepulauan Sumatera.

Lumuik Suliki ini, pertama kali ditemukan saat pergolakan tahun 1960-an silam, ketika masyarakat bersembunyi di perbukitan Hulu Bonda, Jorong Padang 
Loweh, Nagari Suliki, Limapuluh Kota. Penemuan batu lumuik Suliki, sebenarnya bukan disengaja,.karena bersembunyi di hutan belantara dan di sela-sela perbukitan, warga melihat bebatuan yang mengkilat. Setelah diasah secara manual, ternyata batubatu itu menyembulkan kristal-kristal dengan kadar kekerasan yang cukup tinggi.

Batu akik lumuik Suliki beragam jenis, sedikitnya ada 19 jenis yang sudah diproduksi pengrajin batu akik. Di antaranya, jenis Suto, logam, mayang taurai, lumut merah, lumuik hijau, lumuik pandan, kerawang, bekasi, lumuik kuning, anggur, batuang serumpun dan lain. Ada tiga jenis batu akik Suliki terkenal dari kawasan ini adalah suto, logam dan mayang taurai. Ketiga jenis batu tersebut dijual pengrajin dengan harga tinggi per buah. Batu akik suto misalnya mampu berobah robah warna, sedangkan di dalam batu akik kekuningan berwarna emas, lagipula airnya hijau. Begitu juga dengan mayang taurai kilatnya memukau peminat. Nama-nama batu mulia tersebut masih merujuk pada tampilan dan cirri-ciri khasnya, belum merujuk pada nama-nama ilmiah mineral-mineral yang bersesuaian.

Identifikasi ilmiah dan genesa tentang batu akik Suliki belum ada yang melaporkannya. Hal inilah yang mungkin menyebabkan batu mulia ini tidak banyak dikenal secara internasional, kalah pamor dengan batu permata dari negara lain seperti batu mulia dari Thailand, Kamboja, India dan daerah lainnya. Hal tersebut diungkapkan oleh pakar geologi Sumbar, Ade Edward (saat ditemui Tim Pengabdian pada tanggal 24/01/2015).

Batu akik asal Suliki mulai dipromosikan sejak tahun 1989 dan sangat populer sampai ke pelosok-pelosok Sumatera Barat (Padang Gemastone, 2014). Pada tahun 2012 perantau asal Limapuluh Kota yang berada di Perantauan seperti Riau, Jakarta sudah "keranjingan" dengan batu akik ini. Namun demikian, batu akik /batu mulia tersebut dijual masih dalam bentuk potongan yang belum digosok (batu aslinya) dan sudah digosok terbatas dalam bentuk bulat atau bulat lonjong untuk keperluan perhiasan seperti cincin, liontin kalung, dan anting-anting. Bentuk-bentuk atau desaindesain lainnya perlu dikembangkan sehingga memberikan nilai tambah yang lebih. Salah seorang perajin batu akik Suliki adalah Bapak Datuk (56 tahun). Datuk adalah generasi kedua di Kecamatan Suliki, Limapuluh Kota, yang bertahan "hidup" dengan mengasah batu akik lumuik Suliki secara tradisional.

Dari hasil survey pada awal Januari 2014, Tim Pengabdian Masyarakat mewancarai Roni (35 tahun) salah seorang pengrajin batu akik Suliki dan tokoh pemuda menuturkan, banyaknya penggemar lumuik Suliki yang datang ke pengrajin batu akik di Suliki, tak hanya kalangan masyarakat umum, tapi juga kalangan pejabat, perusahaan swasta, kontaktor untuk membeli bahan mentah dan sedikit yang membeli yang sudah jadi. Pengrajin ini menuturkan bahwa kerajinan yang digelutinya sebatas menerima pesanan penggosokan batu mulia menjadi batu halus dengan "ster" atau cahaya pendar yang tepat. Peralatannyapun masih sangat terbatas. Roni dan sejumlah pengrajin lainnya, membelikan sebuah "mesin pemarut kelapa" yang dimodifikasi menjadi 'mesin' pengasah batu. Belakangan, berkat "mesin pemarut kelapa" modifikasi tersebut, Roni bersama-sama rekannya bisa menerima order penggosokan batu-batu alam Suliki menjadi perhiasan tangan "batu akik" dan kalung. Roni ingin mengembangkan usahanya, namun banyak hal yang masih menghambat. Di samping peralatan yang masih terbatas dan sederhana, jenis produk kerajinannya juga masih terbatas. Pamor batu akik lumuik Suliki tidak lagi secerah periode 2011-2013. Roni juga menuturkan beberapa perajin sudah sepi 
orderan/pemesanan, termasuk beliau yang kini tetap menekuni usaha ini sebagai usaha utama.

Kemunduran pamor pamor Batu Akik Suliki dan penurunan omset penjualan produk kerajinan batu akik di wilayah Suliki menurut penuturan kedua pengrajin ini disebabkan oleh beberapa faktor. Pertama, pemasaran batu akik (batu mulia) yang masih terbatas walaupun peminat batu akik (batu mulia) semakin banyak seiring dengan kemajuan teknologi informasi yang mengungkap berbagai keunikan, komoditas batu akik juga bagian dari jenis industri kreatif yang dapat memberi banyak manfaat, namun peluang ini belum bisa ditangkap oleh para pengrajin batu akik di wilayah Suliki yang hanya mengandalkan keunggulan batu alam Suliki yang memiliki keunikan semata.

Hal ini perpulang pada masalah yang kedua yaitu masalah produksi, mulai dari keterbatasan bahan baku karena adanya spirit pelestarian dan pengendalian eksplorasi, keterbatasan teknologi produksi karena peralatan yang digunakan masih sangat sederhana, dan desain produk yang masih terbatas. Dengan mempertimbangkan keterbatasan bahan baku dan kelangkaannya maka perlu usaha-usaha untuk memberi nilai tambah terhadap serpihan atau bubuk batu alam tersebut.

Ketiga, persoalan klasik yang juga dihadapi oleh mitra pengrajin adalah manajemen keuangan usaha dan rumah tangga masih menyatu sehingga tidak mengetahui apakah usahanya dalam keadaan untung atau rugi. Teknologi komputer dan teknologi informasi dan komunikasi yang berkembang sangat cepat dan telah terbukti sangat membatu dalam manajemen produksi dan manajemen pemasaran belum dimanfaatkan secara optimal oleh mitra.

Tantangan baru yang dihadapi para pengrajin batuakik lumuik Suliki adalah perlindungan hak atas karya intelektual
(HaKI). Isu terbaru yang menggema adalah kemerosotan industri kerajinan Sumatera Barat banyak diakibatkan oleh rendahnya pemahaman terhadap perlindungan HaKI. Banyaknya barang tiruan di pasaran dan semuanya mengklaim "batu lumuik Suliki, Sumatera Barat" termasuk mudahnya desain-desain ditiru bahkan diklaim kepemilikannya oleh orang lain baik asing maupun berduit menjadi kekhawatiran para pengrajin di bumi Minangkabau termasuk para pengrajin batu akik Suliki.

Kegiatan yang dilaksanakan ini terinspirasi dari persoalan dan tantangan yang dihadapi para pengerajin Batuakik Lumuik Suliki digolongkan menjadi permasalahan produksi dan permasalahan manajemen. Permasalahan produksi yang telah dapat dipetakan

Peraturan Nagari tentang ijin masuk hutan kawasan perbukitan Suliki serta pengendalian eksplorasi dan eksploitasi sumberdaya batu mulia yang terkandung di dalamnya) sehingga batu mulia dimanfaatkan seoptimal mungkin sehingga memberi nilai tambah yang tinggi. Oleh karena itu, peralatan produksi perlu direvitalisasi dan dengan asupan teknologi pemanfatan sisa pengolahan batu akik (berupa serpihan dan bubuk) untuk menjadi produk kerajinan melalui teknik recovery batu mulia.

Refleksi bersama tentang mengapa terjadinya menurun pemesanan batu akik Suliki siap pakai menghasilkan justifikasi tentang pentingnya manajemen usaha berbantukan komputer dan teknologi informasi dan komunikasi baik ditingkat produksi (mulai desain hingga finishing) maupun di tingkat pemasaran (pemasaran on-line atau melalui website). Oleh karena itu perlu dukungan konten promosi berupa sebuah buku tentang sejarah, mitos, khasiat, kajian ilmiah, dan kajian sosiokultural dan religiusitas dari batu akik Suliki. Buku ini akan menjadi wahana untuk membangkitkan 
pamor batu akik Suliki; dan Kekhawatiran bahwa karya cipta dan intelektual yang terkandung dalam kerajinan batu akik Suliki terancam diambilalih oleh para pemodal besar maupun pihak lain menyebabkan timbulnya kesepakatan terhadap kegiatan tentang pemahaman terhadap HaKI dan tata cara penelusuran dan penentuan kelayakan HaKI produk-produk kerajinan batu akik melalui sosialisasi HaKI.

\section{METODE PELAKSANAAN}

Metode dan pendekatan yang ditawarkan untuk mengatasi persoalan, kebutuhan dan tantangan mitra sesuai dengan skala prioritas yang telah disepakati adalah:

(1) Metode alih IPTEK yaitu transfer pengetahuan tentang revitalisasi peralatan produksi kerajinan batu Akik (pengenalan cara kerja alat-alat produksi yang lebih maju dan melalui bantuan mesin utama yang diperlukan) serta pembuatan kerajian batu akik dari bubuk sisa pengolahan batu mulia. Mitra sangat tertarik untuk mengembangkan karena merupakan solusi tepat mengatasi keterbatasan bahan baku.

(2) Metode pelatihan dan pendampingan manajemen produksi dan manajemen pemasaran berbantukan komputer dan TIK. Pelatihan ini melibatkan tenaga pelatih yang memiliki kompetensi tidak saja komputer dan TIK tetapi juga manajemen produksi dan pemasaran.

(3) Pendekatan sosiokultural dan metode triangulasi digunakan untuk penyusunan buku Batu Akik Suliki. Data-data kualitatif dan kuantitatif yang berhasil digali dari berbagai sumber selanjutnya dianalisis triangulatif sehingga diperoleh bahan-bahan yang sahih untuk penyusunan buku tersebut.

(4) Metode sosialisasi partisipatif digunakan untuk meningkatkan kesadaran dan pemahaman mitra terhadap pentingnya HaKI dan metode pendampingan untuk meningkatkan kemampuan mitra dalam menelusuri produk-produk kerajinan berbasis batu mulia yang layak untuk di usulkan mendapatkan HaKI.

Selama kegiatan berlangsung, mitra diharapkan selalu ikut berpartisipasi secara aktif.

\section{LUARAN}

Luaran dari rangkaian kegiatan ini adalah revitalisasi kerajinan batuakik Lumuik Suliki yang dituangkan dalam sebuah buku. Buku ini memuat berbagai hal berkaitan dengan sejarah dan perjalanan usaha indusitri kerajinan batuakik Lumuik Suliki dari sejak dirintis, mengalami masa kejayaan hingga nasibnya kini merana.

Kemudian dilanjutkan dengan berbagai usaha untuk mengembalikan keemasan industri kerajinan rakyat ini berdasarkan refleksi pengalaman pahit terdahulu dan aplikasi IPTEKS dalam merevitalisasinya.

\subsection{Revitalisasi kerajinan batuakik Lumuik Suliki}

Revitalisasi kerajinan batuakik Lumuik Suliki, Kec. Suliki, Kab.Lima Puluh Kota, Sumatera Barat diawali dengan peremajaan alat produksi yang menyesuaikan dengan kebutuhan desain yang digarap dan ketersediaan fasilitas pendukung lainnya. Peralatan yang lama banyak yang tidak berfungsi lagi, khususnya peralatan yang telah dimiliki oleh mitra IbM.

Telah dilakukan persiapan dan pengadaan peralatan dan cara penggunaannya. Beberapa alat yang diperlukan dalam peoses produksi batu permata antara lain: mesin geride, alat pemotong batu, alat pengasah batu, motor pengerak dan mata bor khusus diamond grade. 


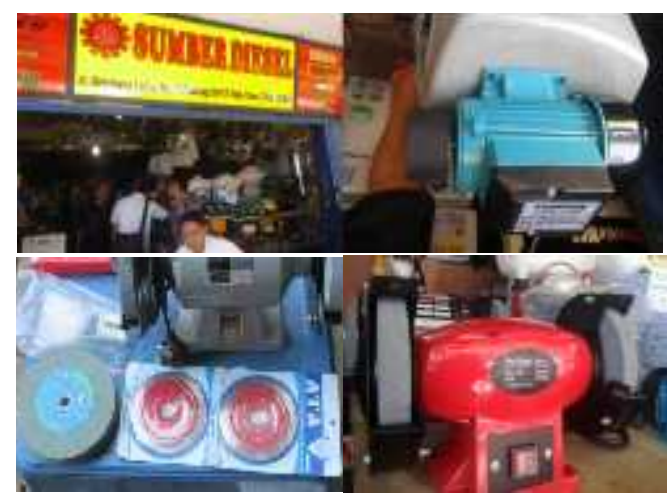

Gambar 1. Peralatan untuk Proses Produksi

Penjelasan dari peralatan yang digunakan dalam merevitalisasi kerajinan batuakik Lumuik Suliki, Kec. Suliki, Kab.Lima Puluh Kota, Sumatera Barat dapat dijabarkan sebagai berikut. Alat pemotong batu (diamond wheel) diperlukan untuk memotong batu mulia. Batu ukuran besar harus dipotong-potong terlebih dahulu sebelum dibentuk lebih lanjut sesuai dengan keperluan dengan alat potong khusus untuk batu permata. Alat potong batu permata yang telah dimiliki berukuran dengan diameter 10 inci dan 5 inci.

Untuk dapat digunakan, alat pemotong batu ini harus dipasang pada mesin pemotong dengan kecepatan tinggi, sekitar $2500 \mathrm{rpm}$, dan daya 2500 WATT, dengan tegangan 220 Volt. Mesin gerinda digunakan untuk memutar batu geride. Mesin ini memiliki putaran sekitar 2500 rpm dan daya 300 WATT. Mesin ini dihubungkan dengan sumber listrik 220 Volt. Batu gerinda (grinding wheel) digunakan untuk mengasah batu yang telah dipotong sesuai kebutuhan, sehingga diperoleh bentuk yang dinginkan, seperti batu berbentuk bulat, batu berbentuk oval, atau bentuk lainnya.

\subsection{Pendampingan Proses Produksi dan Pemasaran Produk}

Kegiatan Pelatihan dan Pendampingan Pengrajin Batu Akik Lumuik Suliki Kec.
Suliki yang diperoleh kemudian dipotong dan dibentuk sesuai dengan desain yang diinginkan dengan alat khusus pemotong batu, lalu diasah dengan gerinde, dihaluskan sampai mengkilap, dan dipasang pada desain perhiasan tertentu, sesuai dengan keperluan.
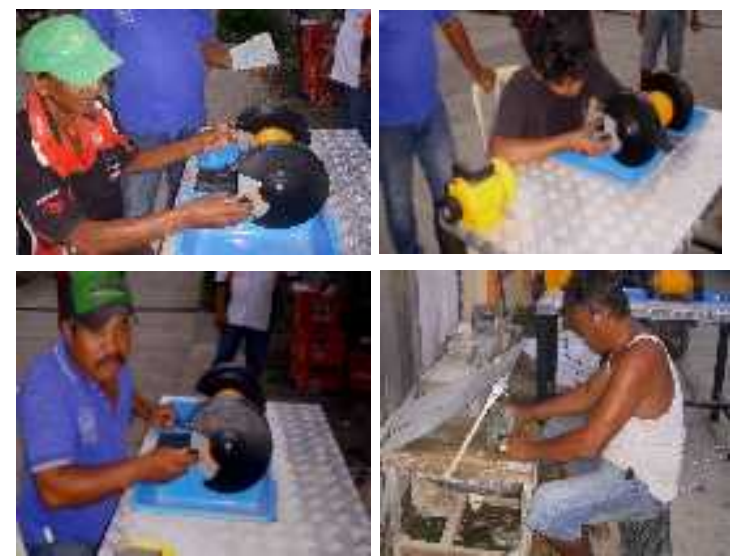

Gambar 2 Kegiatan Pendampingan bagi Pengrajin Batu Akik Lumuik Suliki

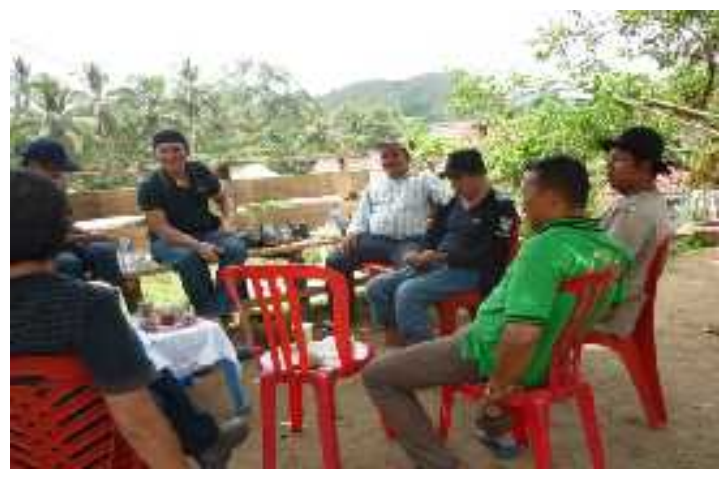

Gambar 3. Kegiatan Pendampingan

Pemasaran Produk Pengrajin Batu Akik Lumuik Suliki

\subsection{Cincin, Perhiasan}

Pada masa lalu pemakai batu akik asal Suliki yang dikenal dengan lumuik Suliki, hanya sebatas di kalangan orang tua-tua saja. Pada masa sekarang perhiasan batu akik diminati mulai dari kalangan remaja sampai tua, sudah menjadi pembicaraan yang luas di kalangan masyarakat pencinta batu akik, bahkan menjadi trending topic bagi banyak kalangan. Telah dibuat beberapa produk cincin lengkap dengan ikatnya dan sumpel 
dari batu akik lumuik Suliki. Ini merupakan produk langka dan susah didapat. Ada beberapa desain dengan berbagai ukuran yang menggunakan bahan perak dan batu mulia dari Suliki sebagai permatanya..

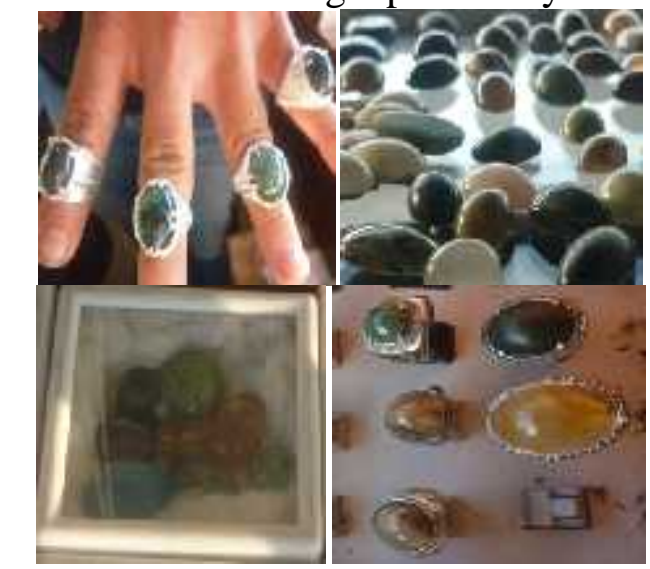

Gambar 4 beberapa desain cincin dengan berbagai ukuran batuakik lumuik Suliki

Beberapa batu mulia yang dapat digali, berwarna kehijauan, Setelah diasah secara manual, ternyata batu-batu itu menyembulkan kristal-kristal dengan kadar kekerasan yang cukup tinggi, dan putih. Setelah melakukan penggalian dan memperoleh batu mulia yang cukup, Tim balik kembali sekitar pukul 14.00 WIB, tiba di Kantor Wali Nagari Suliki

Warga melihat bebatuan yang mengkilat. Setelah diasah secara manual, ternyata batu-batu itu menyembulkan kristalkristal dengan kadar kekerasan yang cukup tinggi. Semenjak itu pula, lumuik Suliki beredar luas di tengah masyarakat. Kawasan perbukitan inilah menjadi lokasi diperoleh berbagai jenis batu alam lumuik suliki yang dikenal sebagai "Giok Sumatera" dan Lumuik Suliki

\subsection{Penyusunan Buku Batu akik Lumuik Suliki}

Survey awal tentang lokasi dan berbagai jenis batuan yang ditemui saat perjalanan selama survey lokasi ditemukannya Batu Akik Lumuik Suliki di hutan kawasan khususnya di wlayah sela-sela perbukitan yang dikenal penduduk setempat sebagai perbukitan Suliki seperti terlihat pada gambar di bawah ini.

Perjalanan ini dimaksudkan tidak saja merasakan bagaimana para pengerajin mendapatkan bahan baku batu, tetapi juga melihat-lihat kondisi perbukitan dan hutan di kawasan tersebut. Percakapan dengan para pengrajin di sepanjang perjalanan dapat merekam permasalahan yang mereka hadapi yang selanjutnya menjadi bahan-bahan dalam menyusun buku tentang berbagai aspek dari kerajinan Batu Akik Lumuik Suliki.

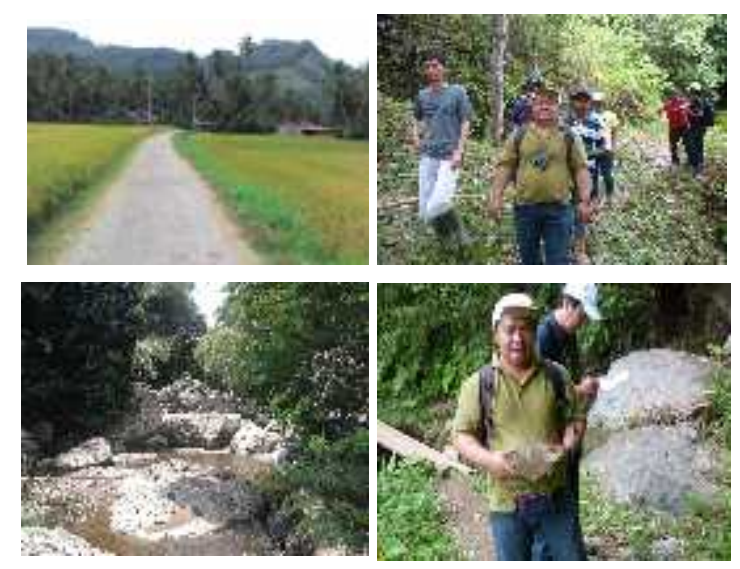

Gambar 5. Perjalanan Awal Dalam Rangka Penyusunan Buku Batu Akik Lumuik Suliki

Perjalanan kedua tim pelaksana bersama mitra pengerajin dan aparat Nagari/desa ke lokasi batu Akik lumuik Suliki yang dikenal oleh penduduk setempat sebagai daerah Perang jaman dulu di wilayah perbukitan Suliki dilakukan dengan maksud untuk mengungkap lebih dalam berbagai hal berkaitan dengan eksplorasi batuakik, kehidupan pengerjain dan berbagai potensi pengembangan, potensi ekonomi dan juga potensi komplik sosial yang ditimbulkan sebagai bentuk triangulasi dari data awal dan data dari berbagai sumber informasi lainnya.

Beberapa batu mulia yang dapat digali, berwarna kehijauan, Setelah diasah secara manual, ternyata batu-batu itu 
menyembulkan kristal-kristal dengan kadar kekerasan yang cukup tinggi, dan putih. Setelah melakukan penggalian dan memperoleh batu mulia yang cukup, Tim balik kembali sekitar pukul 14.00 WIB, tiba di Kantor Wali Nagari Suliki

Warga melihat bebatuan yang mengkilat. Setelah diasah secara manual, ternyata batu-batu itu menyembulkan kristalkristal dengan kadar kekerasan yang cukup tinggi. Semenjak itu pula, lumuik Suliki beredar luas di tengah masyarakat. Kawasan perbukitan inilah menjadi lokasi diperoleh berbagai jenis batu alam lumuik suliki yang dikenal sebagai "Giok Sumatera" dan Lumuik Suliki

\section{KESIMPULAN}

Proses produksi kerajinan Batu Akik Lumuik Suliki telah dapat direvitalisasi dengan peremajaan peralatan produksi sesuai kebutuhan dan daya dukung prasarana lainnya sehingga mitra pengerajin telah dapat memproduksi Kerajinan batuakik Lumuik Suliki sesuai permintaan pasar dan mengembangkan beberapa desain baru yang prospektif. Pemasaran produk kerajinan sudah mulai menggeliat lagi hal ini ditunjukkan dari peningkatan order kerajinan dan peningkatan omzet penjualan yang diperoleh oleh mitra sekitar $30 \%$ dari sebelum direvitalisasi dan memiliki prospek pasar yang lebih tinggi akibat website dan buku batuakik Lumuik Suliki sebagai media promosi.

\section{DAFTAR PUSTAKA}

, 2013, Kabupaten Lima Puluh Kota Dalam Angka, BPS Kab. Lima Puluh Kota.

A Macdonald Orbis Book, 1987. The Macdonald Encyclopedia of Rocks \& Minerals, Macdonald \& Co
(Publishers) Ltd, Greater London House, hamstead Road, London NW1 7QX, 607 hal.

Bates, R.L., and Jackson, J.A., 1980. Glossary of Geology, Second Edition, American Geological Institute, Falls Church, Virginia, 749 hal.

BPS Sumbar, (2013) Sumatera Barat dalam Angka. Padang : Laporan BPS Sumbar.

Chandra, A.F, 2014. Pesona Batu Mulia: Meraup Untung Selangit Melalui Hobi dan Investasi Paling Menguntungkan, Yogyakarta: Sinar Kejora

Danny Z . Herman, 2008. Pendayagunaan mineral untuk menjadi permata, Buletin Sumber Daya Geologi Volume 3 Nomor 3 - 2008, Bandung

Derpartemen Pertambangan dan Energi, 2002, Kegiatan Inventarisasi Pengusahaan Pertambangan Propinsi Sumatera Barat, Tim Subdin Pengusahaan, Dinas Pertambangan dan Energi Propinsi Sumatera Barat

Komunitas Batu Mulia Sumatera Barat, 2014. "Varian Lumuik Suliki", Padang. Tidak dipulikasikan.

Ministry of Trade of The Republic of Indonesia, 2010. Handbook of Commodity Profile, Indonesian Gemstones Exclusively Captivating, Trade Research and Development Agency.

Prasetyowibowo, B. 1999. Desain Produk Industri Bandung. Bandung : Yayasan Delapan Sepuluh. Indonesia. 
Simlitabmas Dikti, 2014, Panduan Pelaksanaan Penelitian dan Pengabdian kepada Masyarakat di Perguruan Tinggi, Edisi IX, Direktorat Penelitian dan Pengabdian kepada Masyarakat Dirjen Pendidikan Tinggi, Kementerian Pendidikan dan Kebudayaan, http://simlitabmas.dikti.go.id/\#, Diakses 29 Maret 2014.

Sujatmiko, J.N, 2014. Kemilau Batu Cincin: Plus Khasiat, Mitos, Misteri, dan Legendanya, Yogyakarta: Kamea Pustaka.

Sujatmiko, J.N, 2014. Potensi Batu Mulia Indonesia Yang Terlupakan, Bandung: Pusat Promosi Batumulia Indonesia.

Padang Gemastone, 2014, Potensi Batu Mulia Sumbar, makalah, Seminar Batu akik Suliki, Smatera Barat. 